Наносистели, нанолатеріали, нанотехнології Nanosistemi, Nanomateriali, Nanotehnologii 2020, т. 18, № 4, сc. 919-928 (c) 2020 ІМФ (Інститут металофізики ім. Г. В. Курдюмова НАН України) Надруковано в Україні. Фотокопіювання дозволено тільки відповідно до ліцензі

PACS numbers: 47.61.-k, 61.05.cp, 68.37.Hk, 68.37.Lp, 78.30.Hv, 81.07.-b, 81.16.Pr

\title{
Synthesis, Characterization and Structural Study of Untreated and Deep Cryotreated Hybrid Nano-Silica-Iron Oxide
}

\author{
G. D. Gokak ${ }^{1}$, S. M. Bapat ${ }^{1}$, R. M. Kulkarni ${ }^{2}$, and S. D. Kulkarni ${ }^{3}$ \\ ${ }^{1}$ Department of Mechanical Engineering, \\ KLS, Gogte Institute of Technology, \\ Belagavi, Karnataka, India \\ ${ }^{2}$ Department of Nanoscience and Nano Technology, \\ KLS, Gogte Institute of Technology, \\ Belagavi, Karnataka, India \\ ${ }^{3}$ Department of Atomic \& Molecular Physics, \\ Manipal Institute of Technology, \\ Manipal Karnataka, India
}

The present work focuses on synthesizing and deep cryotreatment of hybrid Silica-Iron oxide structure followed by finding out the effect of deep cryotreatment on nanoscale structure of nanoparticles by using x-ray powder diffraction, Fourier transform infrared spectroscopy, field emission gun scanning electron microscopy, transmission electron microscope, BrunauerEmmett-Teller surface area analysis. Results show that the deep cryotreatment has no effect on the composition of nanostructure; however, the size of nanostructure is shrinking and specific surface area is increased. Hence, porosity is decreased and indicates possible enhancement in thermal conductivity due to an increase in bonding strength. These cryotreated nanostructures can possibly be suspended in various conventional base fluids for all heattransfer processes with a little compromise on the viscosity of respective base fluids.

Дану роботу зосереджено на синтезі та глибокому кріообробленні гібридної структури оксид заліза-кремнезем з подальшим з'ясуванням впливу глибокого кріоочищення на наномасштабну структуру наночастинок за допомогою дифракції Рентгенових променів, інфрачервоної спектроскопії з Фур'є-перетвором, сканувальної електронної мікроскопії з польовою емісійною гарматою, просвітлювальної електронної мікроскопії, аналізи площі поверхні за Брунауером-Емметтом-Теллером. Результати показують, що глибоке кріооброблення не впливає на склад наноструктури; однак розмір наноструктури зменшується, а питома поверхня збільшується. Отже, пористість зменшується та вказує на можливе підвищення теплоп- 
ровідности за рахунок збільшення міцности зчеплення. Ці кріоочищені наноструктури можуть бути суспендовані в різних звичайних базових рідинах для всіх процесів теплопередачі з невеликим компромісом щодо в’язкости відповідних базових рідин.

Key words: hybrid nano, deep cryotreatment, XRD, FTIR, FEG-SEM, TEM, B.E.T. surface area.

Ключові слова: гібридне нано, глибоке кріообробляння, дифракція Рентгенових променів, інфрачервона спектроскопія з Фур'є-перетвором, сканувальна електронна мікроскопія з польовою емісійною гарматою, просвітлювальна електронна мікроскопія, аналіза площі поверхні за Брунауером-Емметтом-Теллером.

(Received 4 February, 2020; in final version, 14 May, 2020)

\section{INTRODUCTION}

Conventional heat transfer fluids play a significant role in many industrial processes. However, the use of these liquids results in lower heat exchange rates in thermal engineering devices. This is attributed to the lower valve of their thermal conductivity. One of the ways to overcome this hurdle is by suspending ultrafine solid particles in conventional heat transfer fluids such as water, Ethylene Glycol, Brines, etc. to improve their thermal conductivity. The suspension of nanosize particles typically larger than $10 \mathrm{~nm}$ and less than $100 \mathrm{~nm}$ in a base fluid is called a nanofluid. [1]. Hence, one can say that it may be solar energy, machining, lubrication, medicines, food, electronics, fuel cells or any other area of the science and technology nanofluids have indisputably changed the direction of research.

The basic idea of dispersing solid particles in a fluid to improve the thermal conductivity is not the trend of the 21 st century. It finds roots right back from 1873 when Maxwell proposed a theoretical concept of improvement of effective thermal conductivity of liquid/solid suspension. This is because of the fact that solid particles generally possess higher thermal conductivity than any conventional heat transfer fluids.

Various researchers tried their best to augment the inherently poor thermal conductivity of conventional heat-transfer liquids for more than a hundred years. The foremost setback with the use of large -size particles (millimetre \& micrometre) was the quick settling of the particles in fluids the large size particles and the complexity in the production of small particles are the preventive factors for the liquid/solid suspension to be examined for practical applications [2].

Nanotechnology facilitates to overcome these limitations by suspending nanometer-size particles quite stably in fluids instead of largesize particles an important step in the development of nanoscience. 
The results of the experiments carried pioneered by Choi and then followed by others showed that nanoparticles stay suspended longer than millimetre or micrometre particles. In addition, nanofluids exhibit excellent thermal properties and cooling capacity. Hence, nanofluid research could be a cornerstone in the evolution of coolants for various current as well as next-generation applications. Better ability to manage thermal properties transforms into better energy efficiency, compact thermal systems, lesser operating costs, and ecofriendly development [3].

John Philip and P.D. Shima reported that, although the topic of the thermal property of nanofluids is rich with the large database, there are many inconsistent reports on thermal conductivity augmentation. This includes an enhancement in thermal conductivity with a decrease with the size of nanoparticles and otherwise also. This was attributed to the poor characterization of nanofluids and inaccuracies in the measurement techniques. However, in general, most of the studies report inverse relation with particle size [4].

J. Srakar et al. reviewed research, developments, and applications of hybrid nanofluids and concluded that as far as mononanofluids are concerned stability is one of the most vital constraints. Stability of nanoparticles dispersion for a prolonged time and synthesis of homogeneous suspension still a technical challenge. Due to this application front of nanofluids is limited. It is worth to note that hybrid nanofluids are no exception for the same. Suspension of two different types (shape and size) of nanoparticles may cause enhanced viscosity and consequently larger pressure drop and pumping power in comparison with monosuspension nanofluids [5].

L. Shyam Sundar et al. reported that the stability of hybrid nanoparticles in the base fluid is a major challenge, while for mononanofluids, the stability of the particles is accomplished with customary techniques. As far as hybrid nanofluids are concerned, the suspension of two different materials in the base fluid poses a substantial difficulty due to the surface charge, which contrasts from one to another particle [6].

Hence, it can be stated that the advantage of the enhanced thermal conductivity is counteracted by increased viscosity. Both of these factors are greatly influenced by the size of the nanoparticles. Thermal conductivity of nanofluids is inversely proportional to the size, and viscosity of nanofluids is directly proportional to the size of the nanoparticles. However, to synthesize the nanoparticles of the lowermost size is really a herculean task. Hence, one of the via media could be to synthesize nanoparticles by the best available methods and subsequently treat the nanoparticles in such a way that, their size is reduced.

The practice of cryotreatment on metals has been comprehensively used for many years mostly for improving the life of cutting tools. Numerous researchers have reported that cryotreatment applied for 
cutting tools has enhanced the performance. This enhancement was in terms of tool life, either directly or indirectly through related parameters such as wear resistance, hardness, dimensional integrity, etc. [7].

This is mainly due to the refined grain structure. It is a known fact that microstructural changes not only affect mechanical properties but also thermo-physical properties of the cryotreated specimen, which may be a solid or nanoparticle. Hence, it can be considered for the option via media for the reduction in the size of nanoparticles.

Nevertheless, very a few works have been reported to study the effect of cryotreatment on microstructure tests of nanoparticles and consequently their usage in heat transfer technology [8-10]. However, best to the knowledge of the authors, hardly any work has been reported the effect of cryotreatment of the several microstructures of hybrid nanoparticles. The primary objective of this work is to present the effect of deep cryogenic treatment on hybrid silica-iron oxide nanoparticles on the selected structural studies. Consequently, the possibility of using these nanoparticles in various applications.

\section{SYNTHESIS OF NANOPARTICLES}

In literature, many methods have been employed for the preparation of hybrid nanoparticles [6]. In the present work, $\mathrm{Fe}_{2} \mathrm{O}_{3}$ nanoparticles were prepared by simple combustion technique, whereas hybrid nanosilica is
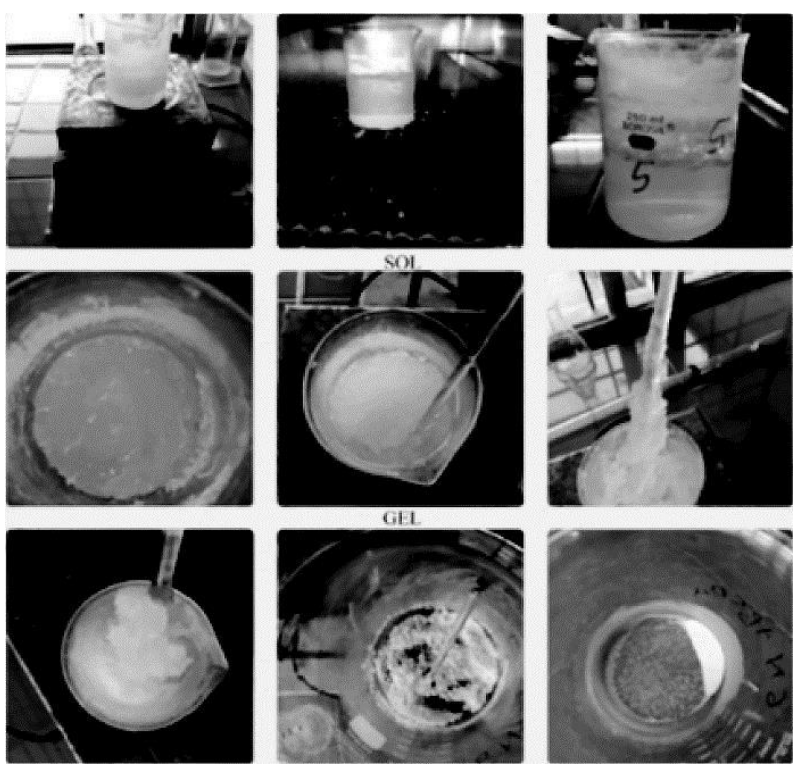

Fig. 1. Synthesis of nanoparticles. 
prepared by using the sol-gel technique in line with the method described by Chate et al. [11]. Sodium silicate and hydrochloric acid are used as primary materials.

Figure 1 shows the apparatus used and the process of preparing the hybrid nanosilica.

\section{CRYOTREATMENT}

As stated earlier, cryotreatment is basically applied to cutting tools to enhance the tool life. However, based on the different factors the cryotreatment or cold treatment can be categorized into three major classes: deep cryogenic treatment (DCT), cryogenic treatment (CT) and sub-zero treatment (SZT). A comparative evaluation DCT, CT, and SZT as applied to tool materials have been given in Table 1 [12].

Shirbhate et al. reported that the soaking temperature and soaking time predominantly affect the performance of the drilling operation. [14]. Hence, deep cryogenic treatment of nanoparticles was selected and carried out at Kryo Space, Pune. The treatment was done at $-193^{\circ} \mathrm{C}(80$ $\mathrm{K})$. Some of the process parameters of treatment are given in Table 2.

TABLE 1. Comparative evaluations of DCT, CT, and SZT.

\begin{tabular}{lcccc}
\hline \multicolumn{1}{c}{ Particular } & DCT & CT & SZT \\
\hline Temperature in K & 80 & 163 & 193 \\
TimeTaken Hrs & $80-100$ & $10-20$ & $5-6$ \\
When to process & any time after & after tempering & within $1 \mathrm{hr}$ of \\
& heat treatment & quenching \\
Wear Resistance & $100-500 \%$ & $30-40 \%$ & max $20 \%$ \\
Stress Relief & complete & some what & no \\
Grain Structure & refines & slight & none \\
\hline
\end{tabular}

Note: *Including tempering if any.

CRYOTREATMENT CYCLE

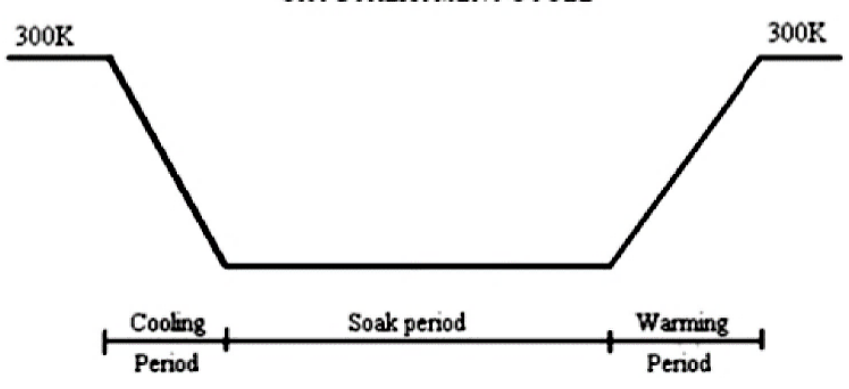

Fig. 2. Cryotreatment cycle. 
TABLE 2. Process parameters employed for deep cryotreatment (DCT).

\begin{tabular}{c|c|c}
\hline Process & Temperature range, K & Time in hrs \\
\hline Cooling & $300-80$ & $24 \mathrm{hrs}$ \\
Soaking & $80-80$ & $24 \mathrm{hrs}$ \\
Warming & $80-300$ & $24 \mathrm{hrs}$ \\
\hline
\end{tabular}
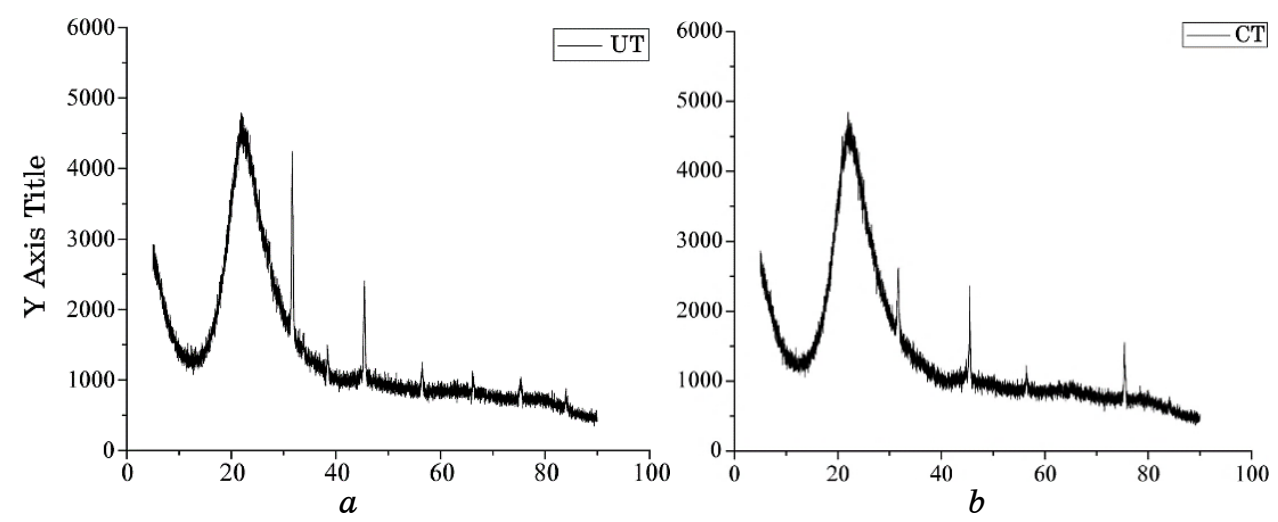

Fig. 3. $a, b$ XRD of UT and CT nanoparticles.

\section{STRUCTURAL STUDY}

To know the effect of the cryotreatment on nanoparticles, following morphological tests were conducted.

\subsection{X-Ray Powder Diffraction (XRD)}

XRD is carried out for phase identification of crystalline material. The XRD patterns are shown in Fig. 3, $a$ (UT) and $b$ (CT).

X-ray powder diffraction (XRD) of Untreated hybrid nanoparticles shows peaks at $31.65^{\circ}, 38.36^{\circ}, 45.42^{\circ}, 56.37^{\circ}, 66.1^{\circ}, 75.2^{\circ}$, whereas XRD of cryotreated hybrid nanoparticles shows peaks at $31.66^{\circ}$, $38.34^{\circ}, 45.48^{\circ}, 56.42^{\circ}, 66.2^{\circ}, 75.38^{\circ}$. In addition, the half-width full maximum for the cryotreated hybrid nanoparticles is less than that of untreated particles. Hence, deep cryotreatment decreases the particle size of the hybrid silica-iron oxide nanoparticles.

\subsection{Fourier Transform Infrared Spectroscopy (FTIR)}

FTIR is for the identification and characterization of a functional group. The same has been shown in Fig. 4, $a$ (UT) and $b$ (CT). 

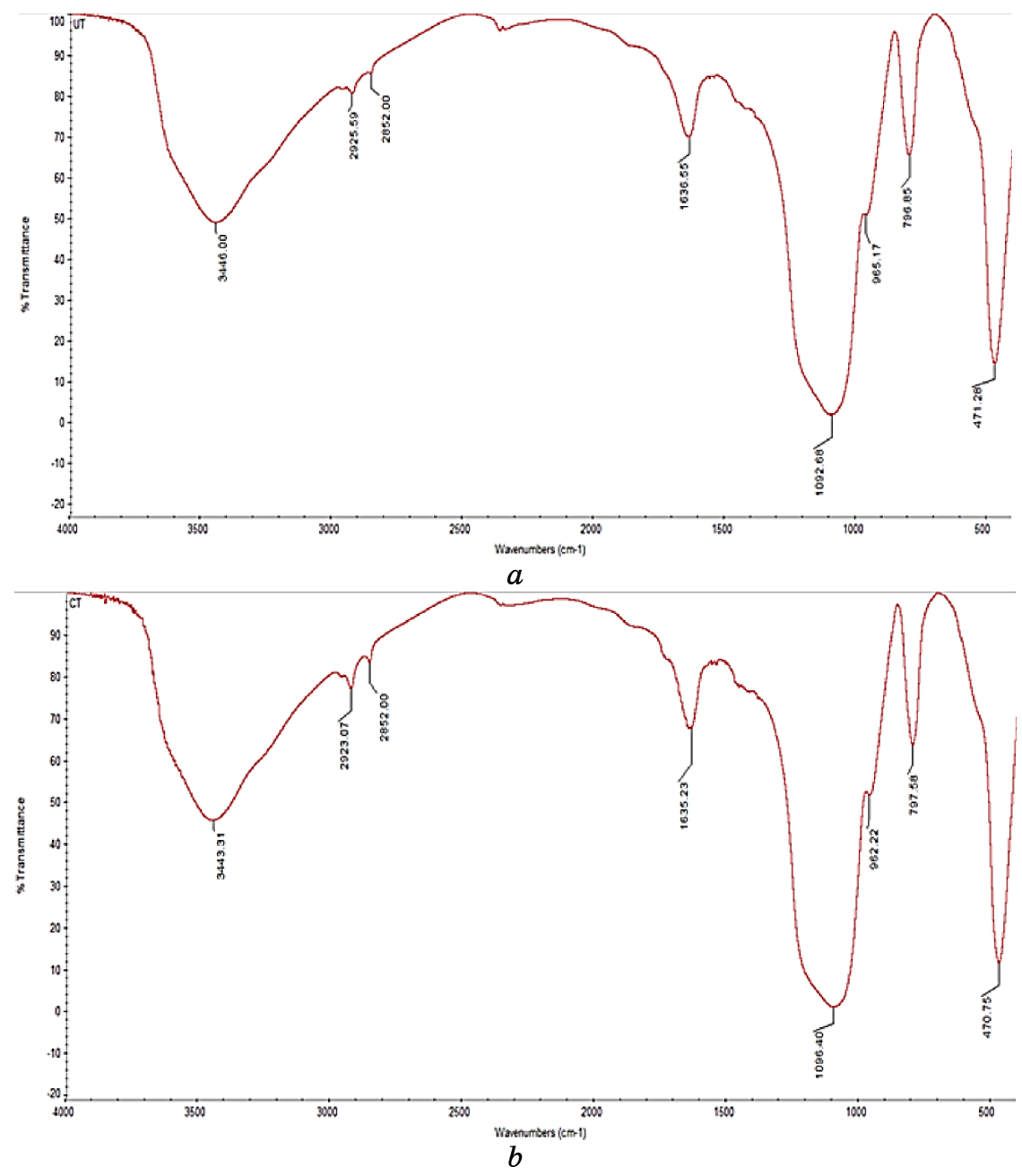

Fig. 4. $a$ and $b$ FTIR of UT and CT nanoparticles.

The test shows no change has been brought by cryotreatment in the composition of the nanoparticles.

\subsection{Field Emission Gun Scanning Electron Microscopy (FEG-SEM)}

FEG-SEM is meant to know the exact composition of the specimen. The images of the same have been shown in Fig. 5, $a$ (UT) and $b$ (CT).

Elemental analysis of untreated and cryotreated hybrid nanoparticles by field emission gun scanning electron microscopy (FEG-SEM) indicates the presence of silicon $(\mathrm{Si})$, iron $(\mathrm{Fe})$ and oxygen $(\mathrm{O})$ elements con- 

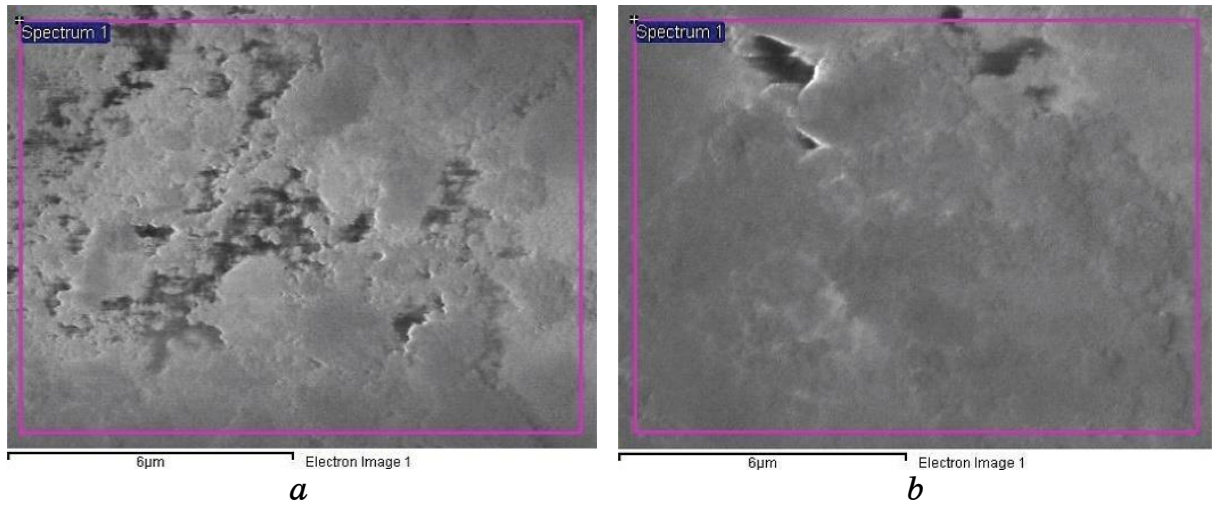

Fig. 5. $a$ and $b$ FEG-SEM of UT and CT nanoparticles.
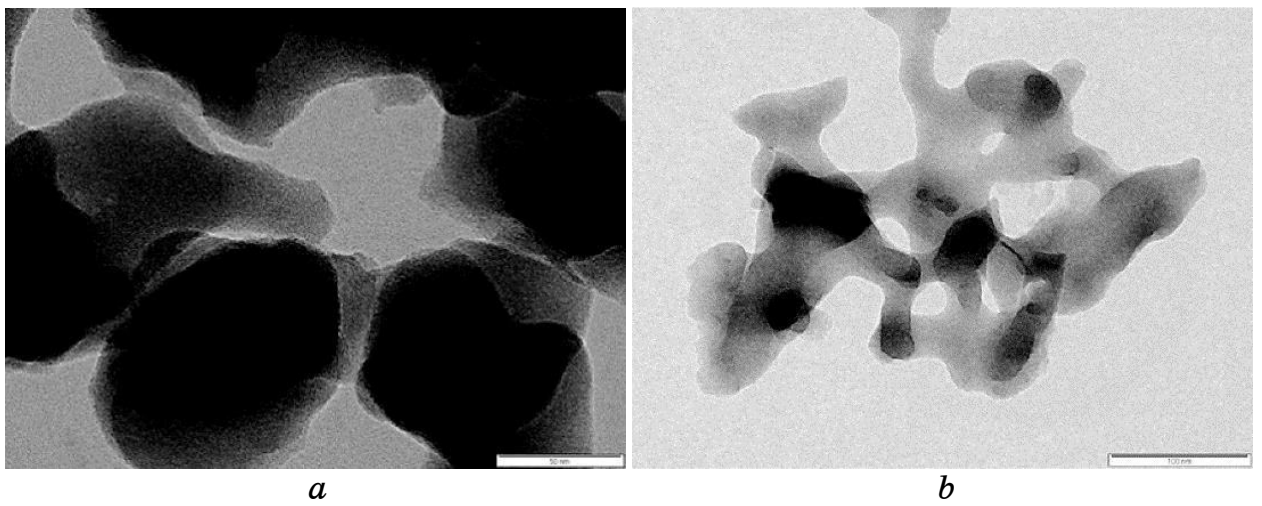

Fig. 6. $a$ and $b$ TEM of UT and CT nanoparticles.

firming hybrid silica-iron oxide $\left(\mathrm{SiO}_{2}-\mathrm{Fe}_{2} \mathrm{O}_{3}\right)$ nanoparticles.

\subsection{Transmission Electron Microscopy (TEM)}

TEM is the most common method employed for magnification details up to $1.000 .000 \times$. The TEM image of both untreated and cryotreated nanoparticles are shown in Fig. 6, $a$ (UT) and $b$ (CT).

It is observed that due to cryotreatment the morphology and size of the nanoparticles have been reduced considerably, which subscribes with XRD results. The reduction in size leads to an increase in strength and thermal conductivity. In addition, the bonding strength of the particles has been enhanced due to cryotreatment, and, compared to untreated particles, the porosity of the nanoparticles has reduced in case of cryotreated particles. 


\subsection{Brunauer-Emmett-Teller (BET) Surface Area}

This test is to know the change in specific surface area of a sample. Surface area measurement shows that the surface area of the hybrid nanoparticles increased from $24.65 \mathrm{~m}^{2} / \mathrm{g}$ to $28.36 \mathrm{~m}^{2} / \mathrm{g}$ after cryotreatment. This also shows reduced porosity in the case of cryotreated nanoparticles. This is in line with TEM analysis.

\section{CONCLUSIONS}

From the morphological tests conducted and their analysis, following conclusions can be drawn.

Deep cryotreatment decreases the particle size of the hybrid silicairon oxide nanoparticles. cles.

Deep cryotreatment did not affect the composition of the nanoparti-

The nanoparticles the specific surface area increased due to deep cryotreatment.

The bonding strength seems to be enhanced due to cryotreatment.

Finally, the authors opine that cryotreated nanoparticles may be employed in various conventional base fluids for all the applications of heat transfer with considerably enhanced thermal conductivity and little compromise on the viscosity of respective base fluids.

\section{ACKNOWLEDGEMENT}

The authors acknowledge USIC Solapur University for XRD, USIC Karnataka University Dharwad for FT-IR, SAIF, IIT Bombay, Mumbai for FEG-SEM and TEM testing. Also, thank Shri. Yusuf Bootwala of Kryo Space Pune (http://www.kryospace.co) for help in carrying out deep cryotreatment of nanoparticles.

\section{REFERENCES}

1. U. S. Choi, ASME FED, 231: 99 (1995).

https://ecotert.com/pdf/196525_From_unt-edu.pdf

2. Huifei Jin, PhD Thesis, Dielectric Strength and Thermal Conductivity of Mineral Oil-Based Nanofluids (2015).

http://citeseerx.ist.psu.edu/viewdoc/download?doi=10.1.1.1003.3415\&rep=r ep1\&type $=$ pdf

3. S. K. Das, S. U. S. Choi, W. Yu, and T. Pradeep, Nanofluids: Science and Technology (Wiley-Interscience: 2008). https://doi.org/10.1002/9780470180693

4. J. Philip and P. D. Shima, Advances in Colloid and Interface Science, 183-184: 30 (2012). https://doi.org/10.1016/j.cis.2012.08.001

5. Jahar Sarkar et al., Renewable and Sustainable Energy Reviews, 43: 164 
(2015). https://doi.org/10.1016/j.rser.2014.11.023

6. L. Syam Sundar et al., Renewable and Sustainable Energy Reviews, 68: 185 (2017). https://doi.org/10.1016/j.rser.2016.09.108

7. S. Akincioğlu, H. Gökkaya, and İ. Uygur, International Journal of Advanced Manufacturing Technology, 78: 1609 (2015). https://doi.org/10.1007/s00170-014-6755-x

8. D. Senthilkumar, Materials and Manufacturing Processes, 29, No. 7: 819 (2014). https://doi.org/10.1080/10426914.2014.892976

9. D. Senthilkumar, Chaiwat Jumpholkul, and Somchai Wongwises, Advances in Materials and Processing Technologies, 4, Iss. 3: 402 (2018). https://doi.org/10.1080/2374068X.2018.1452111

10. D. Senthilkumar, Advances in Materials and Processing Technologies (2018). https://doi.org/10.1080/2374068X.2018.1479821

11. Ganesh R. Chate et al., Silicon, 10, No. 5: 1921 (2018). https://doi.org/10.1007/s12633-017-9705-z

12.http://nebula.wsimg.com/3329ec1455908bc2a28a3b2023b1e46e?AccessKeyId=B BEAE6764025D09ADCE1\&disposition $=0$ \&alloworigin $=1$

13. D. S. Nadig, V. Ramakrishnan, P. Sampathkumaran, and C. S. Prashanth, AIP Conference Proceedings (13-17 June 2011, Spokane, Washington, USA), vol. 1435, p. 133. https://doi.org/10.1063/1.4712089

14. A. D. Shirbhate, N. V. Deshpande, and Y. M. Puri, International Journal of Mechanical Engineering and Robotics Research, 1: 1 (2012). 